[CL]

\title{
Cycling of sulfur in subduction zones: The geochemistry of sulfur in the Mariana Island Arc and back-arc trough
}

\author{
Jeffrey C. Alt ${ }^{a}$, Wayne C. Shanks III ${ }^{b}$ and Michael C. Jackson ${ }^{c}$ \\ ${ }^{a}$ Department of Geological Sciences, 1006 C.C. Little Building, The University of Michigan, Ann Arbor, MI 48109-1063, USA \\ ${ }^{b}$ Branch of Eastern Mineral Resources, U.S. Geological Survey, 954 National Center, Reston, VA 22092, USA \\ ${ }^{c}$ Department of Earth and Planetary Sciences, McGill University, 3450 University Street, Montreal, Que. H3A 2A7, Canada
}

Received November 23, 1992; revision accepted August 16, 1993

\section{ABSTRACT}

\begin{abstract}
The sulfur contents and sulfur isotopic compositions of 24 glassy submarine volcanics from the Mariana Island Arc and back-arc Mariana Trough were determined in order to investigate the hypothesis that subducted seawater sulfur $\left(\delta^{34} \mathrm{~S}=\right.$ $21 \%$ ) is recycled through arc volcanism. Our results for sulfur are similar to those for subaerial arc volcanics: Mariana Arc glasses are enriched in ${ }^{34} \mathrm{~S}\left(\delta^{34} \mathrm{~S}=\right.$ up to $10.3 \%$, mean $=3.8 \%$ ) and depleted in $\mathrm{S}(20-290 \mathrm{ppm}$, mean $=100 \mathrm{ppm})$ relative to MORB ( $850 \mathrm{ppm} \mathrm{S}, \delta^{34} \mathrm{~S}=0.1 \pm 0.5 \%$ ). The back-arc trough basalts contain $200-930 \mathrm{ppm} \mathrm{S}$ and have $\delta^{34} \mathrm{~S}$ values of $1.1 \pm 0.5 \%$, which overlap those for the arc and MORB. The low sulfur contents of the arc and some of the trough glasses are attributed to (1) early loss of small amounts of sulfur through separation of immiscible sulfide and (2) later vapor-melt equilibrium control of sulfur contents and loss of sulfur in a vapor phase from sulfide-undersaturated melts near the minimum in sulfur solubility at $f \mathrm{O}_{2} \approx \mathrm{NNO}$ (nickel-nickel oxide). Although these processes removed sulfur from the melts their effects on the sulfur isotopic compositions of the melts were minimal. Positive trends of $\delta^{34} \mathrm{~S}$ with ${ }^{87} \mathrm{Sr} /{ }^{86} \mathrm{Sr}$, LILE and LREE contents of the arc volcanics are consistent with a metasomatic seawater sulfur component in the depleted sub-arc mantle source. The lack of a ${ }^{34} \mathrm{~S}$-rich slab signature in the trough lavas may be attributed to equilibration of metasomatic fluid with mantle material along the longer pathway from the slab to the source of the trough volcanics. Sulfur is likely to have been transported into the mantle wedge by metasomatic fluid derived from subducted sediments and pore fluids.

Gases extracted from vesicles in arc and back-arc samples are predominantly $\mathrm{H}_{2} \mathrm{O}$, with minor $\mathrm{CO}_{2}$ and traces of $\mathrm{H}_{2} \mathrm{~S}$ and $\mathrm{SO}_{2} . \mathrm{CO}_{2}$ in the arc and back-arc rocks has $\delta^{13} \mathrm{C}$ values of -2.1 to $-13.1 \%$, similar to MORB. These data suggest that degassing of $\mathrm{CO}_{2}$ could explain the slightly lower $\delta^{13} \mathrm{C}$ values for some Mariana Trough volcanic glasses, and that incorporation of subduction-derived organic carbon into the Mariana Trough mantle source may not be necessary. More analyses are required to resolve this question, however.
\end{abstract}

\section{Introduction}

Subduction of oceanic lithosphere at convergent margins is an important global process that carries altered oceanic crust and sediments into the mantle, contributing to geochemical and isotopic heterogeneites there. The subducted slab also provides metasomatic fluids that induce melting in the overlying mantle wedge and alter its trace element and isotopic compositions, which are reflected in island-arc lavas. Rocks from the Mariana and other island and continental arcs are enriched in ${ }^{34} \mathrm{~S}\left(\delta^{34} \mathrm{~S}\right.$ up to $21 \%$ ) relative to MORB $\left(\delta^{34} S \sim 0 \%\right.$ ); this has been attributed to differences in the respective mantle sources, and specifically to recycling of seawater sulfate $\left(\delta^{34} \mathrm{~S}\right.$ $=21 \% 0$ ) or altered oceanic crust into the upper mantle source region for arc magmas [1-5]. Problems of contamination and degassing complicate the interpretation of the arc sulfur data, however. Both intrusive and volcanic subduction related rocks from continental arcs are enriched in ${ }^{34} \mathrm{~S}$ $[1,2,5]$, but their setting in continental crust can result in assimilation of sedimentary sulfide or evaporitic sulfate $[1,5]$. The basaltic and andesitic volcanics from the Japanese and the Mariana island arcs have low $S$ contents $(<100 \mathrm{ppm})$ and widely varying $\delta^{34} \mathrm{~S}$ values $(-0.5$ to $+20.7 \%$ $[3,4,6])$. All of the isotopic data and most of the $S$ content data are for crystalline rocks from sub- 
aerial volcanoes, however, and may be significantly affected by degassing. Moreover, at the low $S$ contents observed the rocks could easily be contaminated by sulfur in volcanic gases, groundwater or sea salts, which would contribute to the wide scatter in measured $\delta^{34} \mathrm{~S}$ values.

In order to test the hypothesis that seawaterderived sulfur is recycled through the upper mantle into arc volcanics, a study of the content and isotopic compositions of sulfur in glassy submarine volcanics from the Mariana Island Arc was undertaken. Glassy submarine rocks were selected because degassing effects should be minimized by the rapid quenching of the glass and by the higher confining pressures of the overlying water column [7]. Contamination effects are minimized because the lack of intergranular pore space in the glass limits penetration of contaminating sulfur-bearing solutions (e.g., seawater or groundwaters), and altered samples can be eliminated through careful cleaning and selection of unaltered fragments for analysis. Glassy rocks from the Mariana Trough back-arc basin (BAB) were also analyzed to investigate whether a ${ }^{34} \mathrm{~S}$ enriched 'arc' sulfur component might be present, and to determine whether $\mathrm{BAB}$ rocks could be distinguished from both arc and MORB glasses on the basis of sulfur geochemistry.

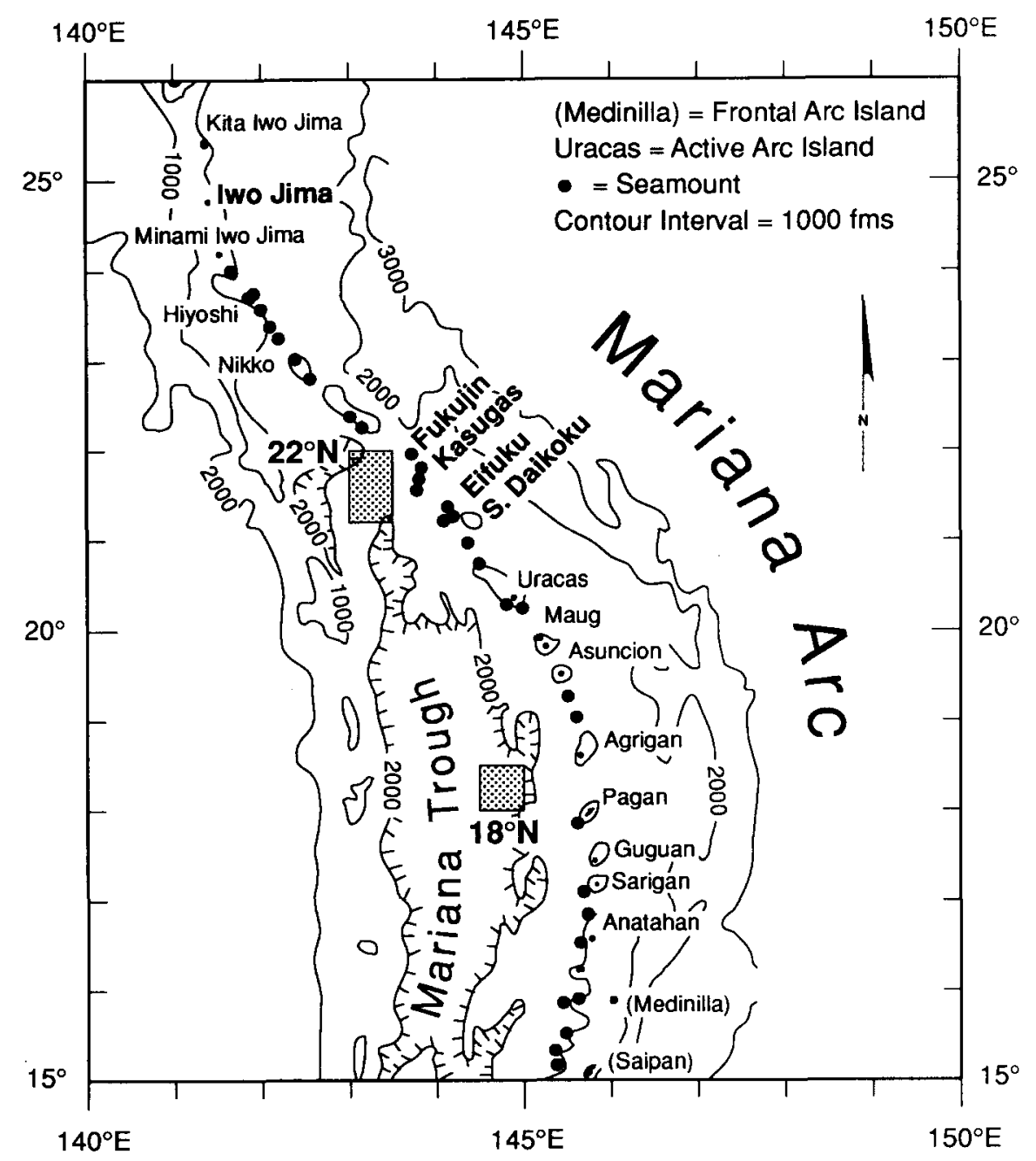

Fig. 1. Bathymetry of the Mariana Island Arc and back-arc trough. $\bullet=$ principal submarine volcanoes. Sampled arc volcanoes (bold lettering) and sampled back-arc areas (stippled boxes) are indicated. Modified from [10]. 


\section{Sampling and methods}

The Mariana Island Arc is located in the western Pacific (Fig. 1) and is situated on oceanic-type crust [8]. West of the island arc, active back-arc spreading occurs within the Mariana Trough, which intersects the northern end of the arc at about $23^{\circ} \mathrm{N}$ (Fig. 1). Geophysical data together with dredging and drilling in the Mariana fore-arc, east of the arc, indicate the absence of an accretionary prism and suggest that sediment and probably fore-arc crust are being subducted beneath the Mariana Arc [8].

Fourteen samples from the northern seamount province of the active Mariana Arc were analyzed (Tables 1 and 2). Ten of these were obtained by dredging of several submarine volcanoes along the volcanic front (Iwo Jima, Fukujin, Eifuku and South Daikoku) at collection depths of 828-1605 $\mathrm{m}$ [6,9-12]. Four samples were also obtained by submersible from the Kasuga arc volcanoes (K2, $\mathrm{K} 3$, and the platform between) at water depths of 1975-2920 m [13]. The Kasuga seamounts form a linear cross-chain extending about $80 \mathrm{~km}$ into the back-arc basin from the volcanic front south of Fukujin (Fig. 1). The arc rocks are mainly basalt and andesite, but range to alkalic high- $\mathrm{K}$ trachyandesites on Iwo Jima and include an absarokite on Kasuga 3 (K3). The ten glassy basalt samples from the back-arc trough were sampled by submersible and dredging at two general locations, $18^{\circ}$ and $22^{\circ} \mathrm{N}[14,15]$.

Polished thin sections were examined for the presence of sulfide minerals and to check for microscale alteration of glass that might affect the analyses. Sections of the crystalline part of the rocks from which glass was sampled were also examined. Samples were classified into three types (Table 2): 'glass' consists of clear, unaltered volcanic glass without or with only traces of crystallites, 'glassy' samples contain abundant microlites or varioles in a matrix of fresh glass, and 'microcrystalline' samples are composed mainly of finely crystalline material set in a groundmass of fresh glass.

The samples were crushed to $1 \mathrm{~mm}$ fragments, washed in distilled water, and hand-picked under a binocular microscope to select glass free of coatings and alteration. The picked samples were ultrasonically washed twice in $10 \% \mathrm{HCl}$ for 10 min each time, then were ultrasonically washed in distilled water three times for $10 \mathrm{~min}$ each time and subsequently examined under a binocular microscope to remove any undesirable fragments. This cleaning technique is similar to that used on submarine MORB and OIB volcanic glass for $S$ analyses [16,17]. The samples were ground to powder and total sulfur was extracted with Kiba reagent (dehydrated phosphoric acid with $\mathrm{SnCl}_{2}$ added) in an $\mathrm{N}_{2}$ atmosphere at $280^{\circ} \mathrm{C}$ [18] and precipitated as $\mathrm{Ag}_{2} \mathrm{~S}$. The latter was combusted under vacuum with $\mathrm{Cu}_{2} \mathrm{O}$ to make $\mathrm{SO}_{2}$ gas for isotopic analysis. Sulfur isotope ratios are reported in standard delta notation relative to the Canyon Diablo Troilite (CDT). Replicate analysis of standards yields a standard deviation of less than $0.2 \%$, although repeated extractions and analyses of samples are reproducible within $0.5 \%$. Absolute variations in $\mathrm{S}$ content from Kiba extractions are less than $10 \%$ of reported values. Multiple tests of the washing, extraction and analysis techniques on a sample of MORB glass yielded a $\delta^{34} \mathrm{~S}$ value of $+0.4 \pm 0.2 \%$ ( $1 \sigma$, Table 1), within the range for MORB glass $\left(\delta^{34} \mathrm{~S}\right.$ $=+0.1 \pm 0.5 \%$ [17,19]).

In an attempt to extract S-bearing gases contained in vesicles in the glass, vacuum crushing experiments were undertaken for several samples (Kasuga and $18^{\circ} \mathrm{N}$ trough samples). Approximately 5-20 g of cleaned, picked sample were placed in a stainless steel tube, which was evacuated and then crushed in a hydraulic press. The tube was heated to $200^{\circ} \mathrm{C}$, and the gases released $\left(\mathrm{H}_{2} \mathrm{O}, \mathrm{CO}_{2}, \mathrm{SO}_{2}\right.$ and $\left.\mathrm{H}_{2} \mathrm{~S}\right)$ were separated by vacuum distillation. $\mathrm{H}_{2} \mathrm{~S}$ was converted to $\mathrm{SO}_{2}$ by reaction with $\mathrm{Cu}_{2} \mathrm{O}$ at $950^{\circ} \mathrm{C}$. Test separations of mixtures of standard gases gave yields within $15 \%$ of starting values, and isotopic analyses of separated gases were within $0.2-1.0 \%$ of original values.

\section{Results}

The arc rocks all have low $\mathrm{S}$ contents, ranging from 20 to $290 \mathrm{ppm} \mathrm{S}$ (Table 1). The two alkalic rocks from Iwo Jima have the highest $S$ contents of the arc rocks (170-290 ppm), whereas the other samples are all less than $200 \mathrm{ppm}$, averaging $70 \mathrm{ppm}$ S. Our average for Fukujin ( $40 \mathrm{ppm}$ ) is similar to the average $\mathrm{S}$ content determined 


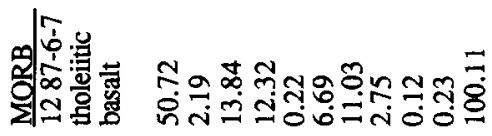

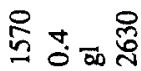

|

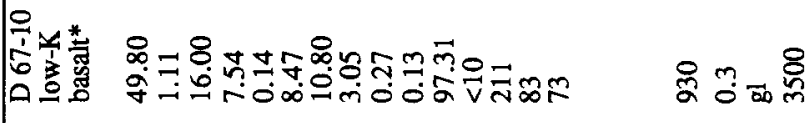

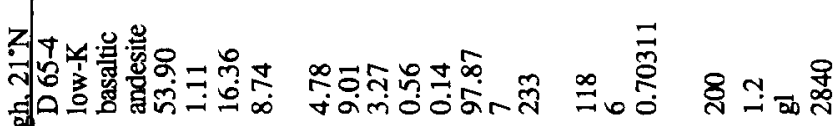
弱

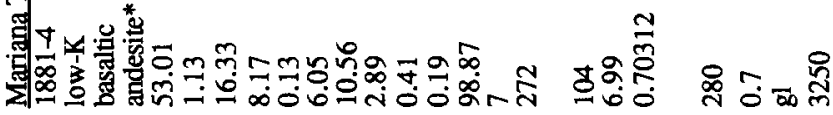

|

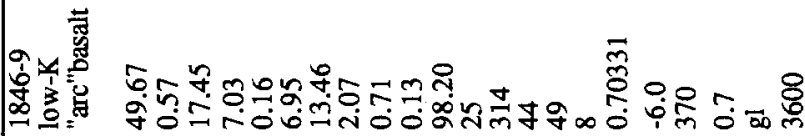

$\infty$

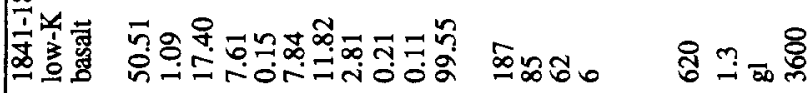

$\hat{n}$

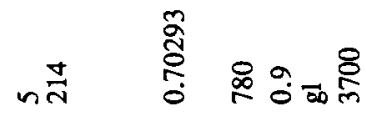

Zm

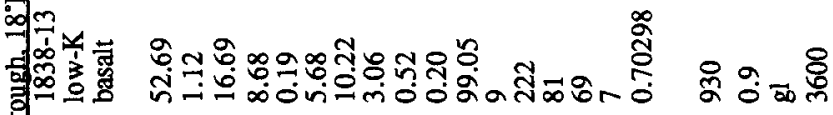

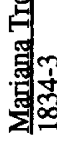

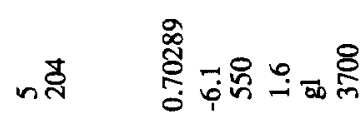

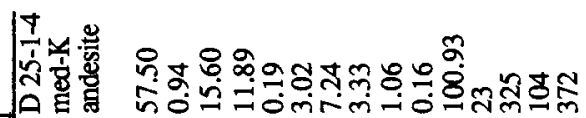

( 


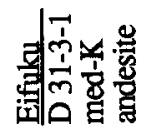

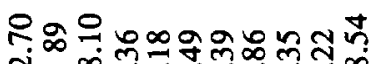

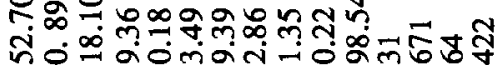

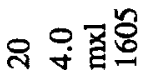

|

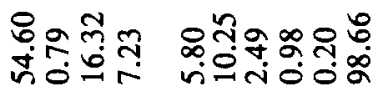

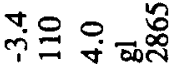

$\widehat{2}$

安

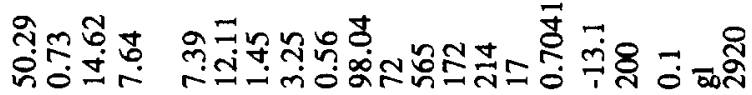

E

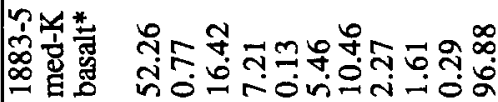

ำำ

$\widehat{\widetilde{\alpha}}$

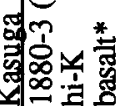

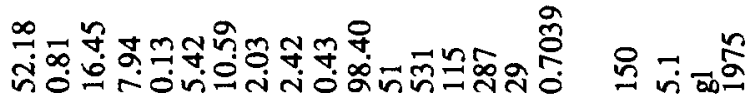

药

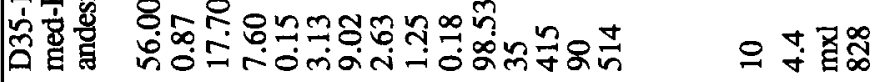

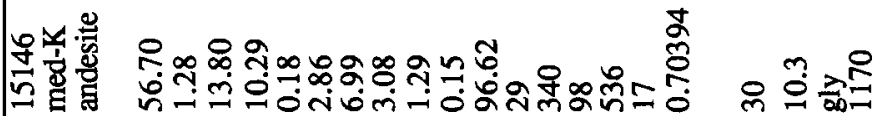

语

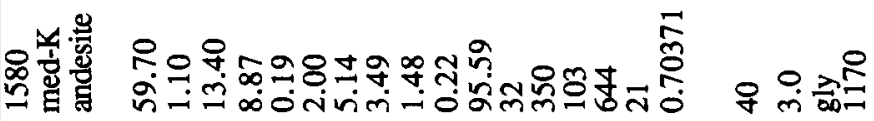

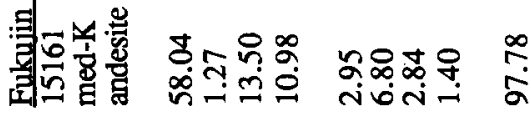

요요을

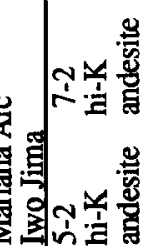

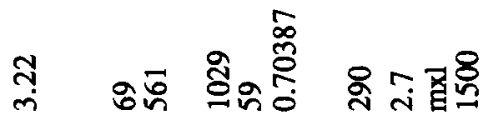

กั่

๙ু

营 


\section{TABLE 2}

Petrography of Mariana and Trough samples

\begin{tabular}{|c|c|c|c|c|c|c|c|}
\hline Mariana Ar & Sample & ${ }^{*}$ Texture & *Sulfides & Alteration & $\%$ Phenos & Phenos & $\%$ Vesicles \\
\hline \multirow[t]{2}{*}{ Iwo Jima } & $5-2$ & $\mathrm{gl}$ & $\overline{\text { nd }}$ & & 3 & $\mathrm{pl}$ & 2 \\
\hline & $7-2$ & gly & nd & & 7 & pl,ol & 3 \\
\hline \multirow[t]{5}{*}{ Fukujin } & $77 \mathbf{k k} 15161$ & gly & $\begin{array}{l}\text { (rare) } 10-15 \text { um in late-crystallizing } \\
\text { areas; } 10 \text { um py attached to } \mathrm{mt} \text { in } \\
\text { xenocrystic "clot" of } \mathrm{mt}+\mathrm{ol}+\mathrm{pl}\end{array}$ & & 10 & pl,mt,ol & 3 \\
\hline & MV 1580 & gly & $\begin{array}{l}\text { (common)1-8um py lining vesicles } \\
\text { partly replaced by Feox }\end{array}$ & & 1 & pl,cpx & 10 \\
\hline & MV 15117 & gly & $\begin{array}{l}\text { interstitial 2-10um cp globules } \\
4-15 \text { um po,py (cp?) lining vesicles } \\
10-20 \text { um po+l-cp }(+p n \text { ?) inclusions } \\
\text { in } m t \text { xenocryst and in cpx+mt of } \\
m t+c p x+m t+a p \text { xenocrystic "clot" }\end{array}$ & & 1 & $\mathrm{pl}, \mathrm{cpx}, \mathrm{mt}$ & 10 \\
\hline & MV 15146 & gly & *(common)1-10um py lining vesicles & & A & & 10 \\
\hline & D 35-1-4 & $\mathbf{m x l}$ & $\begin{array}{l}\text { (v.rare)<1-5um interstital py, cp } \\
1-4 \text { um py/po,cp lining vesicles } \\
1 \text { um cp inclusion in pl phenocryst }\end{array}$ & $\begin{array}{l}\text { trace cc, Feox, } \\
\text { 2ndary cp in cc } \\
\text { veinlet }\end{array}$ & 20 & pl,opx & 1 \\
\hline \multirow[t]{4}{*}{ Kasuga } & $1880-3(K 2)$ & gl & $\begin{array}{l}\text { (v.rare)2-3um po,py lining vesicles, } \\
\text { partly repl. by Fe-oxide }\end{array}$ & & 10 & ol,cpx,sp & 50 \\
\hline & $1883-5$ (platform) & gl & $\begin{array}{l}\text { (v.rare)1-4um sulfides lining vesicles } \\
\text { partly repl. by Fe-oxide; } 2 \text { um po } \\
\text { inclusion in ol }\end{array}$ & & 10 & ol,cpx & 30 \\
\hline & $1884-10(\mathrm{~K} 3)$ & $\mathrm{gl}$ & $\begin{array}{l}\text { (rare) 2um py,cp lining vesicles; } \\
1-2 u m \text { po inclusion in ol phenocryst }\end{array}$ & & 10 & ol,sp & 25 \\
\hline & $1885-6(\mathrm{~K} 3)$ & gl & $1-10 u m$ py lining vesicles & & 5 & ol & 30 \\
\hline Eifuku & D $31-3-1$ & gly & $\begin{array}{l}\text { (common) 2-10um py,po lining } \\
\text { vesicles; (rare)interstital 5-8um po }\end{array}$ & & 20 & $\mathrm{pl}, \mathrm{ol}, \mathrm{cpx}$ & 5 \\
\hline \multirow[t]{2}{*}{ S. Daikoku } & D 25-3 & $\mathrm{mxl}$ & $\begin{array}{l}\text { (common) <1-10um py,po lining } \\
\text { vesicles; 2um cp inlcusion in pl pheno. }\end{array}$ & & 20 & $\mathrm{pl}, \mathrm{ol}, \mathrm{cpx}$ & 5 \\
\hline & D 25-14 & gly & $\begin{array}{l}\text { (v.rare) interstital 10um cp+mt; } \\
\text { 2um cp inclusion in mt xenocryst; } \\
\text { 10um cp interstital in pl+cpx+mt } \\
\text { xenocrystic clot }\end{array}$ & & 5 & pl,cpx & 1 \\
\hline \multicolumn{8}{|c|}{ Back-Arc Trough } \\
\hline \multirow[t]{6}{*}{$18 \mathrm{oN}$} & $1834-3$ & gl & na & & 10 & pl & $<1$ \\
\hline & $1838-13$ & gl & na & & 1 & pl & 15 \\
\hline & $1839-3$ & gl & na & & 5 & pl & 5 \\
\hline & $1841-18$ & $\mathrm{gl}$ & na & & 10 & $\mathrm{pl}$ & 3 \\
\hline & $1846-9$ & $\mathrm{gl}$ & na & & 10 & pl & 15 \\
\hline & $1846-12$ & gl & na & & A & & 5 \\
\hline \multirow[t]{4}{*}{$210 \mathrm{~N}$} & $1881-4$ & $\mathrm{gl}$ & (rare) 1-5um py lining vesicles & & 5 & pl,ol,cpx & 10 \\
\hline & D $65-4$ & gl & (rare) $<1$ um py/po lining vesicles & & A & & 15 \\
\hline & D $67-10$ & gl & $\begin{array}{l}\text { 1-2um po/py lining vesicles } \\
\text { (rare) 2-5um po/py in glass }\end{array}$ & & A & & 1 \\
\hline & D 68-4 & $\mathrm{gl}$ & (v.rare) 2 um po/py lining vesicles & & 10 & pl & \\
\hline MORB & $87 \mathrm{MW} 12$ 87-6-7 & $\mathrm{gl}$ & na & & & & \\
\hline
\end{tabular}

Textural abbreviations are in the footnote to Table 1. na and $n d=$ not analysed and not determined. $c p=$ chalcoppyrite $c p x=$ clinopyroxene $m t=$ magnetite $o l=$ olivine $o p x=$ orthopyroxene $p l=$ plagioclase $; p o=$ pyrrhotite $p y=$ pyrite; $s p=s p i n e l$ 
previously by mass spectrometry for four glassy samples from Fukujin (60 ppm [6]). The BAB basalts range from 200 to $930 \mathrm{ppm} \mathrm{S}$, with a mean of $610 \mathrm{ppm}$. These values overlap the low end for MORB glasses (640-1800 ppm [7,17,19]), but extend to even lower values and overlap the highest $S$ contents for the arc samples.

Most of the arc samples have $\delta^{34} \mathrm{~S}$ values of +1.4 to $+5.5 \%$ (Table 1 ), and tend to be enriched in ${ }^{34} S$ relative to MORB glass $\left(\delta^{34} \mathrm{~S}=\right.$ $+0.1 \pm 0.5 \%$ [17]). The absarokite from Kasuga Seamount has the lowest $\delta^{34} \mathrm{~S}$ value measured for any of the arc samples $(+0.1 \% 0)$, and one sample from Fukujin has a high $\delta^{34} \mathrm{~S}$ value of $10.3 \%$ (Table 1). The BAB basalts have $\delta^{34} \mathrm{~S}$ values ranging from +0.3 to $+1.9 \%$, with a mean of $+1.1 \pm 0.5 \%$ (Table 1 ). These values fall approximately between those for MORB and those for the arc rocks.

Sulfur contents and $\delta^{34} \mathrm{~S}$ values have previously been reported for basalt glasses from the Mariana Trough and from the Sumisu Rift backarc spreading center $[20,21]$. The results indicate sulfur contents of 130-699 ppm, similar to those reported in Table 1 . The previously reported $\delta^{34} \mathrm{~S}$ values for Mariana Trough and Sumisu Rift back-arc basalts are somewhat lower than those in Table 1 , averaging $-0.7 \pm 0.5 \%$ o $[20,21]$. The cleaning technique used by these two studies ( $3 \mathrm{~N}$ $\mathrm{HCl}$ at $60^{\circ} \mathrm{C}$ for $1 \mathrm{~h}$ ) was more aggressive than that used in our study (room temperature in $10 \%$ $\mathrm{HCl}$ twice for $10 \mathrm{~min}$ each time plus distilled water rinse), and could easily have leached sulfide minerals or even sulfur dissolved in the glass. If the sulfur lost had high $\delta^{34} \mathrm{~S}$ values (e.g., sulfate dissolved in glass, and vesicle-lining sulfides formed from $\mathrm{SO}_{2}$ vapor-see below), this could account for their lower values.

With the exception of the Iwo Jima samples, where no sulfides were observed, the arc rocks generally contain trace amounts of sulfide minerals. The most common occurrence of sulfides in the arc rocks is the $<1-10 \mu \mathrm{m}$ pyrite and pyrrhotite crystals lining vesicles (Table 2 and Fig. 2A). These are similar to the sulfide blebs lining vesicles in MORB glass, which are interpreted to have formed by reaction of sulfur in the gas phase contained in the vesicle with $\mathrm{Fe}$ in the glass of the vesicle walls [7,22]. Small $(<1-10$ $\mu \mathrm{m})$ anhedral grains and globules of pyrite and
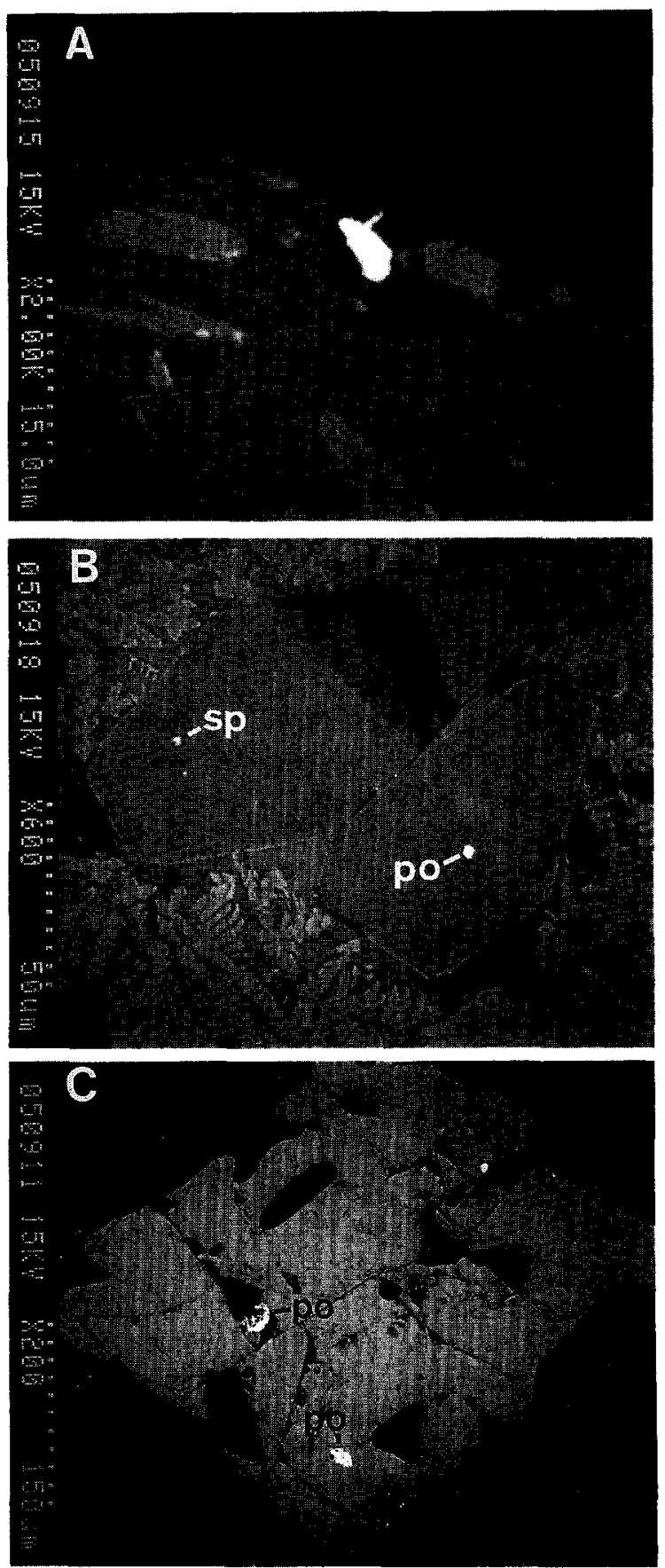

Fig. 2. Back-scattered electron photomicrographs of sulfide minerals in Mariana Arc volcanics. (A) Pyrite bleb ( $p y$ ) lining vesicle wall. Sample 15117 from Fukujin. (B) Pyrrhotite ( $p o$ ) and $\mathrm{Cr}$-spinel $(s p)$ inclusions in olivine phenocrysts. Sample 1884-10 from Kasuga. (C) Pyrrhotite ( $p o$ ) inclusions in magnetite phenocryst associated with plagioclase + olivine crystal clot. Sample 15117 from Fukujin. 
chalcopyrite ( \pm magnetite) occur very rarely in the arc samples, as interstitial grains and in latecrystallizing areas of some glassy and microcrystalline samples (Table 2). These are fairly common in thin sections of the crystalline parts of most of the arc rocks, and are attributed to sulfide saturation during progressive crystallization of the rocks. Six of the fourteen arc samples contain trace amounts of sulfides as inclusions in phenocrysts (Table 2 and Fig. 2B). Like the arc rocks, the $\mathrm{BAB}$ glasses contain trace amounts of small $(<1-5 \mu \mathrm{m})$ pyrite and pyrrhotite grains lining vesicles. Only rarely were immiscible sulfide globules observed in the glass itself (Table 2).

Gases were extracted by vacuum crushing from three of the Kasuga Arc samples and from two of the $18^{\circ} \mathrm{N}$ trough samples. The recovered gases are predominantly $\mathrm{H}_{2} \mathrm{O}$, with minor $\mathrm{CO}_{2}$, and traces of $\mathrm{SO}_{2}$ and $\mathrm{H}_{2} \mathrm{~S}$. Although $\mathrm{SO}_{2}$ and $\mathrm{H}_{2} \mathrm{~S}$ produced small deflections on the vacuum gauge, even the largest sample (approximately $20 \mathrm{~g}$ ) did not produce enough $\mathrm{SO}_{2}$ or $\mathrm{H}_{2} \mathrm{~S}$ to measure in the manometer (less than $1 \mu$ mole) or analyze $S$ isotope ratios. Sufficient $\mathrm{CO}_{2}$ for $\mathrm{C}$-isotopic measurements was obtained from the vesicles from all the samples crushed, however. $\mathrm{CO}_{2}$ from the three Kasuga samples has $\delta^{13} \mathrm{C}$ values ranging from -2.1 to $-13.1 \%$, whilst that from the two trough samples has values of about $-6 \%$ (Table 1).

\section{Discussion}

Volcanics from the Mariana Island Arc are enriched in LILE ( $\mathrm{K}, \mathrm{Rb}, \mathrm{Sr}, \mathrm{Ba})$ and LREE, contain more radiogenic $\mathrm{Sr}$ and $\mathrm{Pb}$, and are depleted in HFSE ( $\mathrm{Ti}, \mathrm{Nb}, \mathrm{Ta}$ ) compared to MORB [4,9-13,23,24]. The low HFSE contents of arc lavas are generally attributed to removal of these elements from the mantle source during prior partial melting and extraction of MORB liquids, whereas the LILE and LREE enrichments are interpreted to be the result of subsequent metasomatism of the depleted sub-arc mantle by hydrous fluids or melts derived from the subducting slab.

The volcanic glasses analyzed in this study exhibit generally positive correlations of $\delta^{34} \mathrm{~S}$ values with ${ }^{87} \mathrm{Sr} /{ }^{86} \mathrm{Sr}$, LILE and LREE contents from MORB to the back-arc trough to the arc
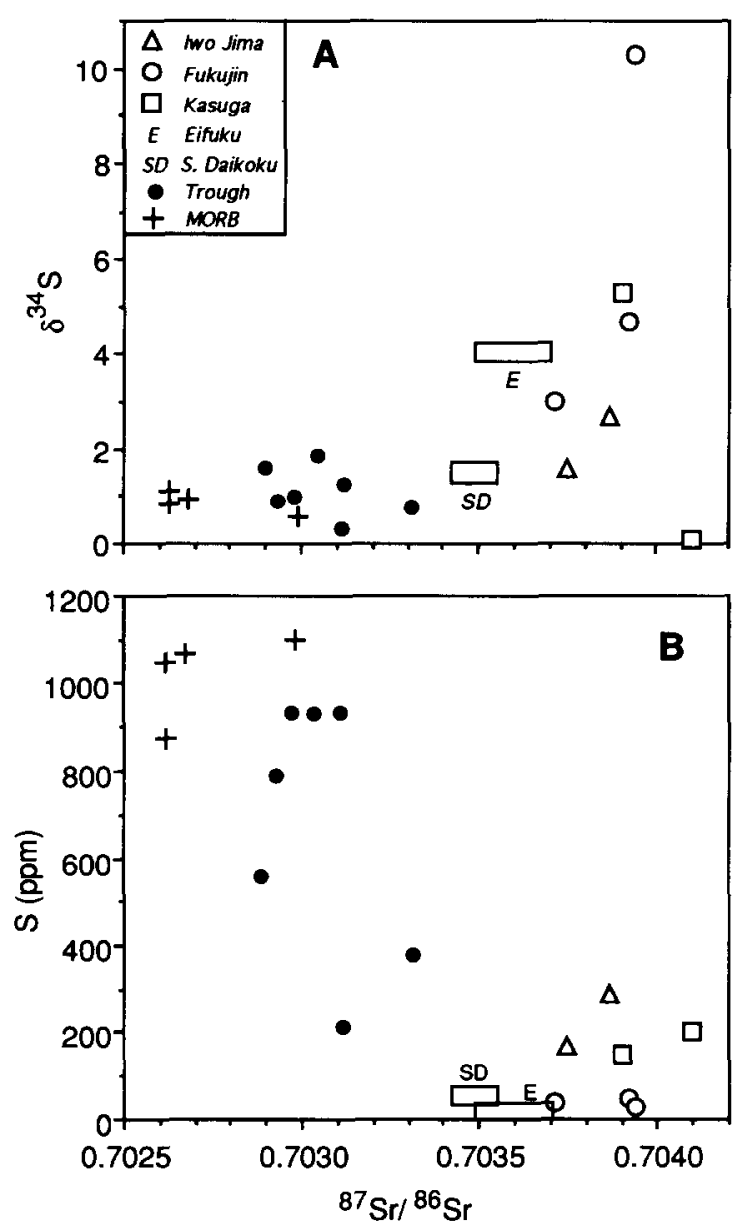

Fig. 3. Sulfur isotope ratios and $\mathrm{S}$ contents versus ${ }^{87} \mathrm{Sr} /{ }^{86} \mathrm{Sr}$ for Mariana Arc and back-arc trough samples. General trends of increasing $\delta^{34} \mathrm{~S}$ contents with increasing ${ }^{87} \mathrm{Sr} /{ }^{86} \mathrm{Sr}$ from MORB to trough to arc samples are attributed to metasomatism of the mantle by a subduction component. Absarokite sample from Kasuga falls off the main trend. MORB glass data from [19]. Because $S$ and $S r$ isotopic analyses were not made on the same samples from Eifuku and South Daikoku, these data are plotted as boxes representing the range of measured $\delta^{34} \mathrm{~S}$ values in Table 1 and of reported ${ }^{87} \mathrm{Sr} /{ }^{86} \mathrm{Sr}$ values from [12] (six $\mathrm{Sr}$ isotopic analyses for each volcano).

(e.g., Figs. 3A and 4), whereas sulfur contents decrease in the same order (e.g., Fig. 3B). These trends suggest that the ${ }^{34} \mathrm{~S}$ enrichments may result from metasomatism of the mantle by a slabderived component, and that the metasomatized mantle source might also be depleted in S. In order to test these hypotheses, processes affecting the sulfur contents of the lavas must be assessed, and the effects of these processes on the 

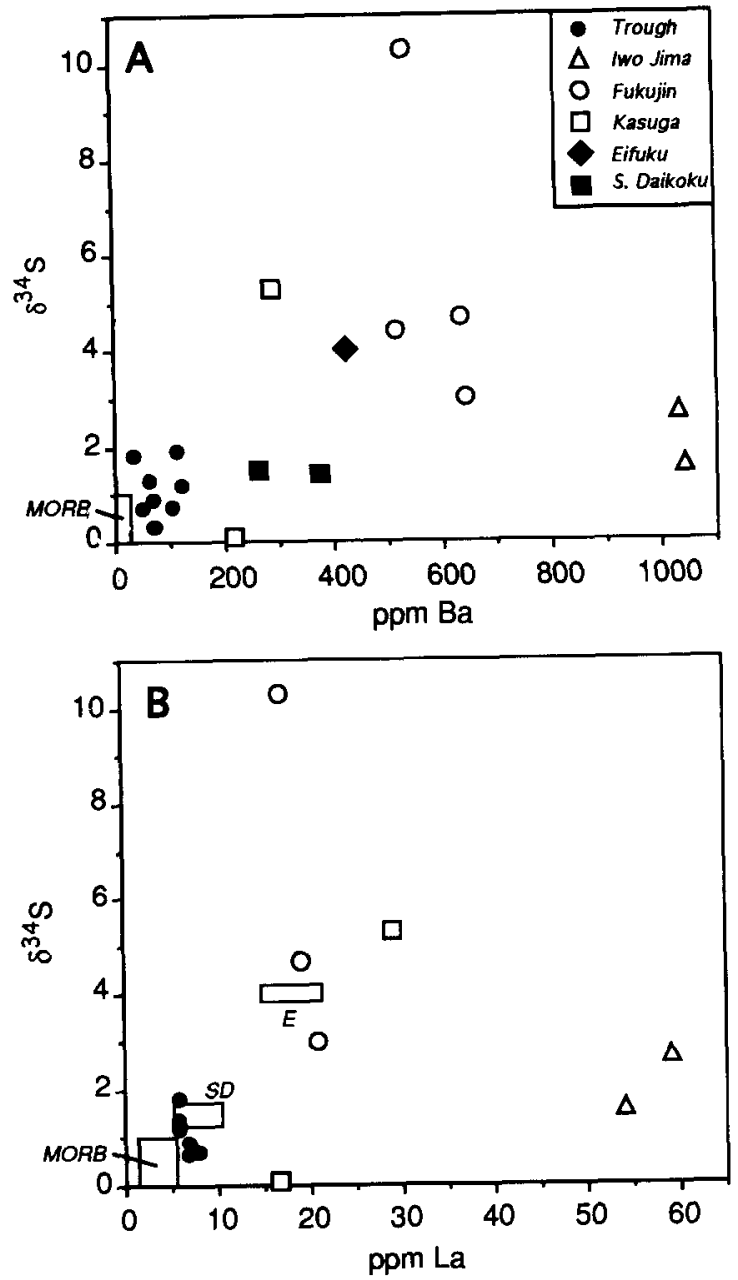

Fig. 4. $\delta^{34} \mathrm{~S}$ vs. (A) $\mathrm{Ba}$ and (B) La for Mariana Arc and Trough samples. General increases in $\delta^{34} \mathrm{~S}$ with $\mathrm{Ba}$ and $\mathrm{La}$ are attributed to metasomatism of the mantle by a subduction component. The alkalic rocks from Iwo Jima fall off the main trends at high $\mathrm{Ba}$ and $\mathrm{La}$ contents, relecting an OlB-like mantle source component $[11,12]$. MORB data represent range of data for submarine volcanic glasses [17,19,56,57]. Because S isotopic and $\mathrm{La}$ analyses were not made on the same samples from Eifuku and South Daikoku, these data are plotted as boxes in (B), representing the range of measured $\delta^{34} \mathrm{~S}$ (Table 1) and reported La contents [11] (six La analyses for each volcano).

isotopic compositions of sulfur in the rocks evaluated.

\subsection{Partial melting}

If arc magmas are derived from melting of mantle that has been depleted during prior ex- traction of MORB liquids, the sulfur contents of arc melts may be limited by the amount of sulfur remaining in the depleted mantle source. The presence of immiscible sulfide in residual peridotites, cumulate gabbros, as inclusions in MORB phenocrysts, and in MORB glasses all indicate that MORBs are saturated with sulfide during melting and throughout most of their crystallization history [25-28]. Extraction of 15-20\% MORB melt containing $800-1000$ ppm $S[7,17]$ from primitive mantle having a sulfur content of $200 \mathrm{ppm} \mathrm{[29]} \mathrm{would} \mathrm{leave} \mathrm{0-90} \mathrm{ppm} \mathrm{S}$ in the residual depleted mantle. Boninites, which are generally accepted as being derived from largefraction partial melts of depleted mantle under hydrous conditions, are interpreted to reflect second-stage, S-undersaturated melting of such a depleted mantle source [25]. Because $S$ behaves as an incompatible element during melting a 30 $35 \%$ partial melt of residual peridotite containing $50 \mathrm{ppm} \mathrm{S}$ would be limited by the amount of sulfur in the source and would have a sulfur content of only $140-170 \mathrm{ppm}$, generally consistent with the low $\mathrm{S}$ contents of glassy boninites $(<130 \mathrm{ppm}$ [25]). The effects of two-stage melting and variable sulfur saturation state are also reflected in the chalcophile element contents of MORBs and boninites. During melting and differentiation of MORB, chalcophile elements (e.g., $\mathrm{Cu}, \mathrm{Pt}, \mathrm{Pd})$ are fractionated into residual and cumulate sulfide phases, which are later wholly incorporated into the S-undersaturated, secondstage boninitic melts, resulting in the high chalcophile element contents of boninites compared to MORB $[25,26]$.

Most arc rocks probably formed by smaller degrees of partial melting than boninites, however. A typical $15-20 \%$ partial melt of residual mantle containing $50-90 \mathrm{ppm} \mathrm{S}$ would contain $330-600 \mathrm{ppm} \mathrm{S}$. Although in this case the $\mathrm{S}$ content of the melt is still limited by the amount of sulfur in the source, the sulfur content of the melt is greater than that measured in the arc glasses (mostly $<200 \mathrm{ppm}$, Table 1), suggesting that other processes caused the low sulfur contents of the arc melts.

Because arc magmas may be derived from a mantle source from which a MORB melt has already been removed, it is necessary to constrain the sulfur isotopic composition of the depleted 
mantle residue. At $\mathrm{fO}_{2}$ less than about NNO (nickel-nickel oxide), sulfur is dissolved in silicate melts mainly as $\mathrm{S}^{2-}$ complexed with $\mathrm{Fe}^{2+}$, whereas at $\mathrm{fO}_{2}$ greater than NNO the dominant sulfur species in the melt is $\mathrm{SO}_{4}^{2-}$, presumably complexed as $\mathrm{CaSO}_{4}$ [30-34]. Because MORBs are generated at low $f_{2}[1-2 \log$ units below FMQ (fayalite-magnetite-quartz)], essentially all the sulfur in both the basalt melt and residual peridotite should be present as sulfide [27], and isotopic fractionation between oxidized and reduced sulfur can be ignored. At the high temperatures of mantle partial melting, fractionation of sulfur isotopes between sulfide in the MORB liquid and in the residuum should be negligible. The amount of fractionation of sulfur isotopes during removal of sulfide from silicate melts is not known, but the $\delta^{34} \mathrm{~S}$ values of unaltered cumulate seafloor gabbros $\left(\delta^{34} \mathrm{~S}=0.8 \pm 0.9 \%\right.$ o [28]) containing cumulate sulfide minerals are essentially identical to those of MORB volcanic glasses $(0.1 \pm 0.5 \%$ o, [17]), suggesting that no significant isotopic fractionation occurs during removal of sulfide from the magma. Thus, the residual MORB mantle should retain its primary sulfur isotopic signature of near $0 \%$.

There is a systematic increase in the proportion of sulfate to total $\mathrm{S}$ in silicate melts with increasing $\mathrm{H}_{2} \mathrm{O}$ contents and $f \mathrm{O}_{2}$, from $\mathrm{SO}_{4} / \Sigma \mathrm{S}$ $<0.1$ for most MORB to approximately equal proportions of $\mathrm{SO}_{4}^{2-}$ and $\mathrm{S}^{2-}$ in arc basaltic andesites and andesites at $f \mathrm{O}_{2} \approx \mathrm{NNO}$ to $1 \mathrm{log}$ unit above NNO [27,30-34]. Because of the presence of significant amounts of both reduced and oxidized sulfur in arc melts, fractionation of sulfur between oxidized and reduced species can affect the isotopic composition of the melt during partial melting and during separation of immiscible sulfide from the melt.

In order to address the question of whether the ${ }^{34} \mathrm{~S}$ enrichments of the arc lavas could be produced by fractionation from a mantle containing MORB-like sulfur $\left(\delta^{34} \mathrm{~S}=0.1 \%\right.$ ) , the isotopic compositions of sulfur in coexisting silicate melt and mantle source were calculated for equilibrium batch partial melting under conditions where the amounts of sulfate and sulfide in the melt are equal. A value of $7.5 \%$ was used for the fractionation of $\mathrm{S}$ isotopes between sulfate and sulfide in the melt $\left(\delta^{34} \mathrm{~S}_{\mathrm{SO}_{4}}=-\delta^{34} \mathrm{~S}_{\mathrm{S}^{2-}}[16,17]\right)$, and it was assumed that isotopic fractionation between sulfide in the melt and that in the source is negligible. For $15-20 \%$ melting of primitive, undepleted mantle containing $200 \mathrm{ppm} \mathrm{S}$ and having a $\delta^{34} \mathrm{~S}$ value of MORB $(0.1 \%)$, total sulfur in the melt has $\delta^{34} \mathrm{~S}=0.8-1.6 \%$, so partial melting cannot produce the measured high $\delta^{34} \mathrm{~S}$ values of the arc glasses. Furthermore, if arc melts are derived from depleted mantle the melts may be S-undersaturated with essentially all sulfur partitioned into the melt, resulting in negligible isotopic fractionation. Thus, the sulfur isotopic compositions of partial melts of sub-arc mantle probably closely reflect the isotopic compositions of their sources, i.e. within about $1 \%$.

\subsection{Fractionation of immiscible sulfide}

Volcanics from the Mariana Arc exhibit petrographic and chemical effects of fractional crystallization of olivine, plagioclase and clinopyroxene [10]. The presence of sulfide inclusions in phenocryst phases (Fig. 2 and Table 2) indicates that the melts were saturated with sulfide at various points in their crystallization history prior to eruption, and that immiscible sulfide may have been removed during fractional crystallization, lowering the sulfur contents of the lavas. There are three silicate fractionation trends among the volcanics analyzed in Table 1: tholeiitic (Mariana Trough, South Daikoku, Eifuku and Fukujin), calc-alkaline to shoshonitic (Kasuga), and alkaline (Iwo Jima) [10,11]. The data for the volcanics from South Daikoku, Eifuku and Fukujin indicate a decrease in $\mathrm{Cu}$ content with decreasing $\mathrm{FeO}^{\mathrm{T}}$ (Fig. 5A). The decrease in $\mathrm{FeO}$ corresponds to decreases in $\mathrm{V}$ at increasing $\mathrm{SiO}_{2}$ throughout the arc, and the $\mathrm{Fe}$ and $\mathrm{V}$ decreases are attributed to fractionation of Fe-oxides [10]. The solubility of sulfur in silicate melts decreases with decreasing $\mathrm{FeO}^{\mathrm{T}}$ content of the melts [3032,35 ] and $\mathrm{Cu}$ is partitioned into sulfide, suggesting that the decreasing $\mathrm{Cu}$ contents were caused by sulfide saturation and fractionation of immiscible sulfide. The presence of $\mathrm{Fe}$ - and $\mathrm{Cu}$-sulfide inclusions in magnetite phenocrysts in the Mariana Arc lavas supports this interpretation (Fig. 2 and Table 2). In contrast to the S-undersaturated boninites, the chalcophile element content of arc basalts and andesites are low and similar to 

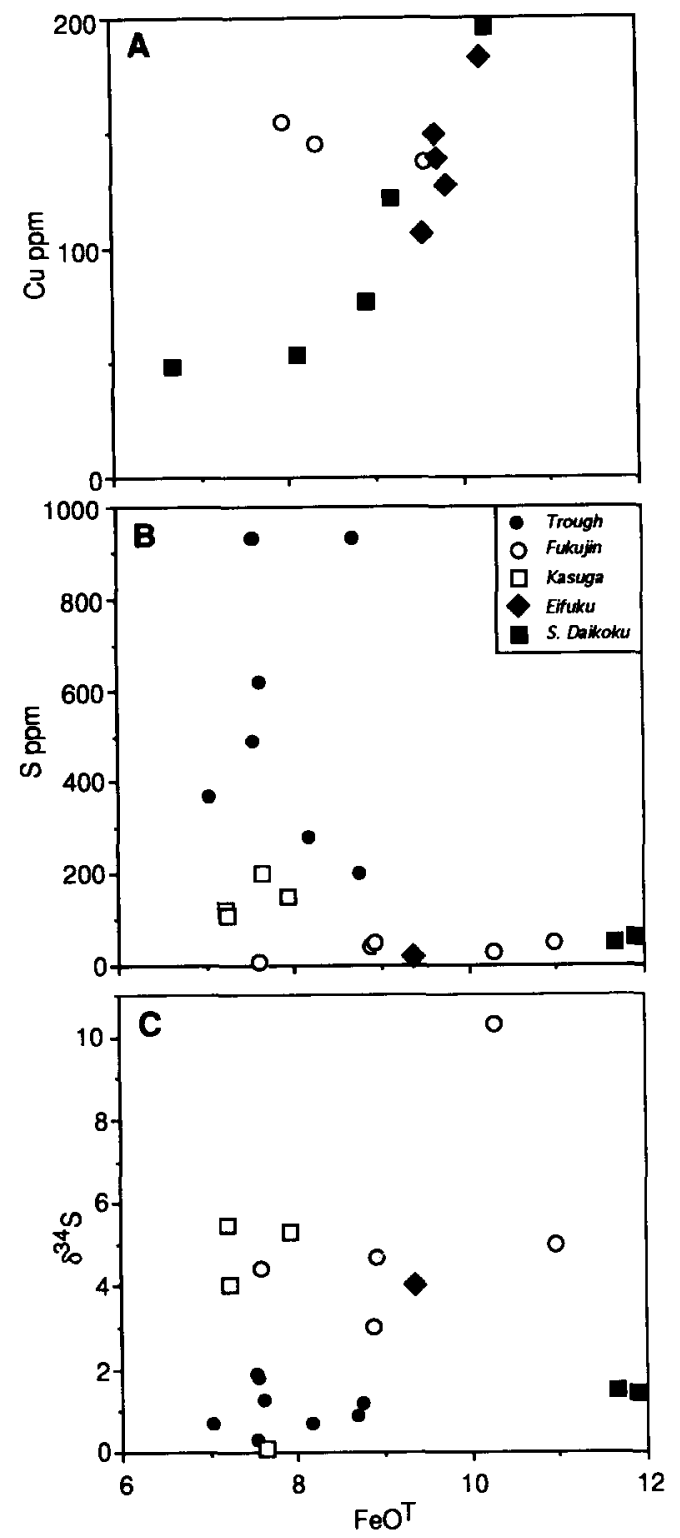

Fig. 5. (A) $\mathrm{Cu}$ contents of Mariana Arc volcanics vs. wt $\%$ $\mathrm{FeO}^{\mathrm{T}}$. Sulfur contents (B) and $\delta^{34} \mathrm{~S}(\mathrm{C})$ vs. wt $\% \mathrm{FeO}^{\mathrm{T}}$ for Mariana Arc and Trough volcanics. $\mathrm{Cu}$ and $\mathrm{FeO}^{\mathrm{T}}$ data in (A) from [10] are not for the same samples as in (B) and (C) or Table 1.

MORB, consistent with sulfide saturation and fractionation of metals into immiscible sulfide [36].

Segregation of immiscible sulfide from a differentiating silicate melt containing both sulfate and sulfide could result in increased $\delta^{34} S$ in the melt. The effect of this process was calculated

starting with a melt having a MORB-like sulfur isotopic composition ( $\delta^{34} \mathrm{~S}=0.1 \%$ ) and containing equal proportions of sulfide and sulfate, assuming (1) negligible fractionation between immiscible sulfide and sulfide in the silicate melt, (2) $\delta^{34} \mathrm{~S}_{\text {sulfate }}-\delta^{34} \mathrm{~S}_{\text {sulfide }}=7.5 \%$ s.16,17], and (3) that sulfate in the melt re-equilibrates with sulfide remaining in the melt. These conditions require removal of about $75 \%$ of the sulfide initially present to reach the $\delta^{34} \mathrm{~S}$ value of $5 \%$ observed in the arc lavas. A melt starting with $300-600$ ppm S would then contain 75-150 ppm S, similar to the sulfur contents of the arc lavas. If sulfur isotopic fractionation occurs as the result of separation of immiscible sulfide during differentiation, there should be some correlation of $\delta^{34} \mathrm{~S}$ with indicators of silicate differentiation $(\mathrm{FeO}$, $\mathrm{MgO}$ or $\mathrm{SiO}_{2}$ content) in the arc glasses. No such correlations exist, however: $\delta^{34} \mathrm{~S}$ values of 4 $5.5 \%$ occur in rocks with $\mathrm{FeO}^{\mathrm{T}}$ contents that vary from 7 to $11 \mathrm{wt} \%$ (Fig. $5 \mathrm{C}$ ). $\mathrm{MgO}$ and $\mathrm{SiO}_{2}$ in these rocks vary from 6 to $2 \mathrm{wt} \%$ and 52 to 60 wt $\%$, respectively (Table 1 ).

\subsection{Degassing}

Despite the evidence for saturation and removal of immiscible sulfide, two points suggest that the arc and back-arc lavas were generally not saturated with sulfide during eruption: (1) the glasses generally lack the disseminated immiscible sulfide globules that are typically observed in sulfide-saturated MORB melts, and (2) the arc rocks do not exhibit the positive correlation of sulfur contents with $\mathrm{FeO}^{\mathrm{T}}$ that should be observed if sulfur contents were controlled by saturation of the melts with sulfide (Fig. 5B [27]). The small amounts of interstitial sulfide that are observed in the Mariana samples are restricted to the crystalline parts of the rocks and reflect sulfide saturation late during crystallization.

Many of the rocks are highly vesicular, suggesting that degassing may have affected their sulfur contents. Vesicles in Mariana Arc rocks contain predominantly $\mathrm{H}_{2} \mathrm{O}$, indicating saturation of the melts with $\mathrm{H}_{2} \mathrm{O}$. The presence of minor amounts of $\mathrm{CO}_{2}$ and traces of $\mathrm{H}_{2} \mathrm{~S}$ and $\mathrm{SO}_{2}$ in the vesicles suggests that even though the melts were not generally saturated with sulfide, $\mathrm{CO}_{2}$ and sulfur were partitioned into the vapor phase and that 
degassing may have lowered the sulfur contents of the rocks. In the absence of an immiscible sulfide liquid, the solubility of sulfur in silicate melts coexisting with a S-bearing vapor phase is controlled by melt-vapor equilibria [27,30]. Sulfur contents of sulfide-undersaturated silicate melts vary with oxygen fugacity, and are at a minimum at $f \mathrm{O}_{2} \approx \mathrm{NNO}$ to $1 \log$ unit above NNO [30]. MORB crystallizes at $f \mathrm{O}_{2}$ approximately 1-2 log units below FMQ, whereas basaltic andesites from arc environments crystallize at $\mathrm{fO}_{2}$ approximately equal to NNO $[27,33,37]$, coinciding with the minimum in sulfur solubility. Thus, loss of sulfur-bearing vapor from sulfideundersaturated melts crystallizing near the minimum in solubility at $f \mathrm{O}_{2} \approx \mathrm{NNO}$ may have contributed to the low $\mathrm{S}$ contents of the submarine Mariana Arc lavas.

Degassing effects might be expected to be more pronounced at shallower water depths corresponding to lower confining pressures, but there is no clear correlation of $\delta^{34} \mathrm{~S}, \mathrm{~S}$ contents, or the amount of vesicles in the arc rocks with collection depth, despite collection at water depths ranging from 828 to $2960 \mathrm{~m}$ (Tables 1 and 2). Low vesicle abundances could indicate either undegassed or extensively degassed lavas, however.

Because of the ${ }^{34} \mathrm{~S}$ enrichment of oxidized compared to reduced sulfur species $\left(\mathrm{SO}_{4}>\mathrm{SO}_{2}\right.$ $>\mathrm{H}_{2} \mathrm{~S}$ ), the effect of degassing of sulfur on the $\delta^{34} \mathrm{~S}$ of the magma depends on which major volatile species are present $\left(\mathrm{SO}_{2}\right.$ or $\left.\mathrm{H}_{2} \mathrm{~S}\right)$ and on the speciation of sulfur in the melt (proportions of $\mathrm{SO}_{4}^{2-}$ and $\mathrm{S}^{2-}$ ). Assuming equilibrium among the various sulfur species in gas and melt phases, the fractionation of sulfur isotopes between vapor and melt can be calculated from

$$
\begin{aligned}
1000 & \ln \alpha_{\text {gas }- \text { melt }} \\
\approx & \delta^{34} \mathrm{~S}_{\mathrm{gas}}-\delta^{34} \mathrm{~S}_{\text {melt }} \\
= & {\left[X \delta^{34} \mathrm{~S}_{\mathrm{SO}_{2}}+(1-X) \delta^{34} \mathrm{~S}_{\mathrm{H}_{2} \mathrm{~S}}\right] } \\
& -\left[Y \delta^{34} \mathrm{~S}_{\text {sulfide }}+(1-Y) \delta^{34} \mathrm{~S}_{\text {sulfate }}\right] \\
\approx & 1000 \ln \alpha_{\mathrm{SO}_{2} \text {-sulfide }} \\
& -(1-X) 1000 \ln \alpha_{\mathrm{SO}_{2}-\mathrm{H}_{2} \mathrm{~S}} \\
& -(1-Y) 1000 \ln \alpha_{\text {sulfate-sulfide }}
\end{aligned}
$$

where $X=\left(\mathrm{SO}_{2} / \mathrm{H}_{2} \mathrm{~S}+\mathrm{SO}_{2}\right)_{\text {vapor }}$ and $Y$ is sulfide $/ \Sigma S_{\text {melt }}$ [16]. High-temperature $\left(>500^{\circ} \mathrm{C}\right)$

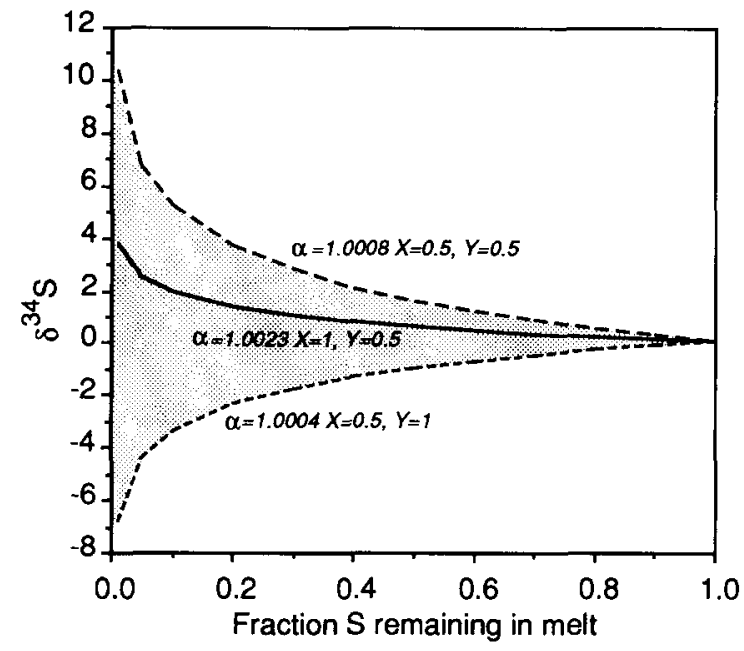

Fig. 6. Sulfur isotopic composition of silicate melt in equilibrium with $\mathrm{S}$-bearing vapor during open-system (Rayleigh fractionation) degassing. Lines indicate melt evolution pathways calculated for three different values of $\alpha\left(1000 \ln \alpha_{\text {gas-melt }} \approx\right.$ $\delta^{34} \mathrm{~S}_{\text {gas }}-\delta^{34} \mathrm{~S}_{\text {melt }}$ ), determined by varying values of $X[=$ $\left.\left(\mathrm{SO}_{2} / \mathrm{H}_{2} \mathrm{~S}+\mathrm{SO}_{2}\right)_{\text {vapor }}\right]$ and $Y\left[=(\text { sulfide } / \Sigma \mathrm{S})_{\text {melt }}\right]$, and starting with a MORB-like $\delta^{34} \mathrm{~S}$ value (see text). Shaded area indicates region of possible melt evolution pathways for reasonable values of $X$ and $Y$, but most likely melt evolution pathways lead to ${ }^{34} \mathrm{~S}$ depletions (see text).

subaerial volcanic gases from island arcs contain greater concentrations of $\mathrm{SO}_{2}$ than of $\mathrm{H}_{2} \mathrm{~S}$, consistent with calculations that indicate values of $0.5-1$ for $X$ at $f \mathrm{O}_{2}$ ranging from FMQ to NNO, temperatures of $800-1200^{\circ} \mathrm{C}$, and pressures of 1-1000 atm for both dry and hydrous conditions $[3,30,38,39]$; Y varies from near 1 for MORB up to about 0.5 for arc melts [27,34], and 1000 ln $\alpha_{\mathrm{SO}_{2} \text {-sulfide }}$ at $1000^{\circ} \mathrm{C}$ is approximately $3 \%$ [16]. The calculated sulfur isotopic compositions of melts during open-system degassing (Rayleigh fractionation) for various values of $X$ and $Y$ are shown in Fig. 6. Only the lowest values of $X$ and $Y$ yield $\delta^{34} \mathrm{~S}$ values of $4-5 \%$ for the melt, and these are not reached until loss of more than $85 \%$ of the sulfur originally present. If the arc melts started with 300-600 ppm S these degassed lavas would contain $45-90 \mathrm{ppm} \mathrm{S}$, but only about half of the arc samples fall in this range (Table 1).

The $\delta^{34} \mathrm{~S}$ of total sulfur in high-temperature $\left(>500^{\circ} \mathrm{C}\right)$ subaerial volcanic gases from island arcs ranges from $+0.3 \%$ to $+12.1 \%$, averaging about $+5 \%$ o 38,39$]$. The compositions of these gases indicate that degassing of sulfur from a 
magma having a MORB-like isotopic composition $\left(\delta^{34} \mathrm{~S}=0.1 \%\right.$ ) would result in a decrease in the $\delta^{34} \mathrm{~S}$ of residual $\mathrm{S}$ in the melts, the opposite of the effect required to achieve the observed ${ }^{34} \mathrm{~S}$ enrichment of the arc glasses. Moreover, if the low S contents of some of the Mariana Trough $\mathrm{BAB}$ glasses are the result of volatile loss $[33,34]$, little or no isotopic fractionation of $\mathrm{S}$ occurred because the low-S BAB glasses have the same $\delta^{34} S$ values as the high-S glasses (Table 1). Thus, while calculations suggest that degassing could conceivably enrich the arc lavas in ${ }^{34} \mathrm{~S}$ relative to MORB, data for natural volcanic gases and for $\mathrm{BAB}$ glasses indicate that degassing of a melt having a MORB-like sulfur isotopic composition should not result in the elevated $\delta^{34} \mathrm{~S}$ of the arc glasses.

Additional evidence consistent with this conclusion comes from the analysis of vesicle gases. Volatiles contained in vesicles in MORB glass are predominantly $\mathrm{CO}_{2}$, which has $\delta^{13} \mathrm{C}$ values of -4.2 to $-8.0 \%$, averaging $-6.5 \%$ o $[22,40]$, whereas $\mathrm{CO}_{2}$ in volcanic gases from island arcs has a somewhat wider range of values $(-2$ to $-11 \%$ ) [39]. The highest $\delta^{13} \mathrm{C}$ values of the arc gases are suggested to contain a component derived from subduction of carbonate sediments, whereas the lower values have been attributed to incorporation of organic $\mathrm{C}$ from subducted sediments [39]. Because of the 2-4\%o fractionation of ${ }^{13} \mathrm{C}$ between $\mathrm{CO}_{2}$ vapor and $\mathrm{C}$ in the melt $[40,41]$, the lower $\delta^{13} \mathrm{C}$ values of some arc volcanic gases could be caused by progressive degassing of $\mathrm{CO}_{2}$. Submarine volcanic glasses from Fukujin volcano have low C contents (15-79 ppm) and $\delta^{13} \mathrm{C}$ values $(-24.7$ to $-29.7 \%$ ), which are attributed to extensive degassing at the relatively shallow water depths of sample collection (1100 $m$ [41]). In contrast, vesicles in arc glasses from Kasuga Seamount, sampled at considerably greater water depths (1975-2920 m), contain easily extractable and measureable $\mathrm{CO}_{2}$, which has $\delta^{13} \mathrm{C}$ values of -2.1 to $-13.1 \%$ (Table 1 ). These values are mostly within the range for subaerial volcanic arc gases, suggesting that these samples have not undergone the extensive degassing of $\mathrm{CO}_{2}$ seen at Fukujin. Seven of the nine samples from these two seamounts have $\delta^{34} \mathrm{~S}$ values in the range $3.0-5.5 \%$ (Table 1), and there is no correlation of $\delta^{13} \mathrm{C}$ with $\delta^{34} \mathrm{~S}$ in the Mariana volcanics
(Table 1). If the variations in $\delta^{13} \mathrm{C}$ are caused by degassing of $\mathrm{CO}_{2}$, either degassing has not affected the sulfur isotopic compositions of the rocks or the effects on sulfur are independent of degassing of carbon. Thus, while inconclusive, the vesicle gas data do not support an origin of the ${ }^{34} \mathrm{~S}$ enrichment of the arc volcanics by degassing.

Our two analyses of $\mathrm{CO}_{2}$ from vesicles in Mariana Trough glasses indicate $\delta^{13} \mathrm{C}$ values of $-6 \%$ (Table 1), identical to those for $\mathrm{CO}_{2}$ released by vacuum crushing of MORB vesicles $(-6.5 \pm 1.3 \%$, $[22,40])$. These data suggest that degassing of $\mathrm{CO}_{2}$ could explain the slightly lower $\delta^{13} \mathrm{C}$ value for the only other analysis of carbon in a Mariana Trough volcanic glass, and that incorporation of subduction-derived organic carbon into the Mariana Trough mantle source may not be necessary [41]. More analyses are required to resolve this question, however.

\subsection{Mantle sources and metasomatic component}

The calculations and evidence presented in the preceding discussion indicate that under conditions where both sulfide and sulfate are present in the melt, a combination of partial melting, separation of immiscible sulfide and degassing could conceivably produce the ${ }^{34} \mathrm{~S}$ enrichments of arc volcanics compared to MORB. However, the likelihood of sulfur-undersaturated melting, the lack of any correlation of $\delta^{34} \mathrm{~S}$ value with indicators of differentiation (particularly $\mathrm{FeO}^{\mathrm{T}}$ ) or $\delta^{13} \mathrm{C}$ of vesicle gases, and data for sulfur in natural volcanic gases from island arcs and for $\mathrm{S}$ in Mariana Trough volcanic glasses all argue against this combination of processes as the mechanism producing the ${ }^{34} \mathrm{~S}$ enrichments of the arc volcanics. The alternative is that the $\delta^{34} S$ of the arc volcanics reflects the composition of sulfur in their mantle source(s).

Mariana Arc lavas are interpreted as having been derived from variable combinations of several mantle sources, the main one being a metasomatized depleted mantle source, but also including an inferred OIB mantle source in the northern Marianas, as well as a metasomatically enriched OIB mantle source [10-12,15,23]. Sulfur contents of OIB, as represented by submarine volcanic glasses from Kilauea (540-840 ppm), are only slightly lower than MORB (average $\approx 800-$ 
$1000 \mathrm{ppm}$ ), and the sulfur isotopic compositions of OIB $\left(\delta^{34} \mathrm{~S}=0.5 \pm 0.6 \% 0\right)$ and MORB $(0.1 \pm$ $0.5 \%$ ) are essentially identical $[16,17]$. Thus, OIB and residual MORB mantle sources should be indistinguishable in terms of sulfur systematics.

The main trends toward increasing LILE, LREE and ${ }^{87} \mathrm{Sr} /{ }^{86} \mathrm{Sr}$ in Mariana Arc lavas are interpreted to reflect metasomatism of a depleted MORB mantle source [10-12,15,23,24], so we interpret the general correlation of $\delta^{34} S$ of the lavas with these indicators (Fig. 3 and 4) to also reflect a metasomatic component in the mantle source. Samples from Iwo Jima lie off the main trends, falling at high values of $\mathrm{Ba}$ and $\mathrm{La}$ in Fig. 4. This may be attributed to the presence of a significant component of LREE-enriched or OIB-like mantle in the source for lavas from Iwo Jima and the northern part of the Mariana Arc (north of Nikko Seamount at $23^{\circ} \mathrm{N}$, Fig. 1) $[12,13,29]$. The absarokite from Kasuga Seamount has the highest ${ }^{87} \mathrm{Sr} /{ }^{86} \mathrm{Sr}$ value reported for Mariana Arc lavas, but has relatively low $\mathrm{Ba}$ and $\mathrm{La}$ contents and the lowest $\delta^{34} \mathrm{~S}$ value (Fig. 3 and 4), requiring differences in the mantle source for this sample compared to other Mariana Arc lavas [13].

Data for altered ocean crust indicate the presence of local ${ }^{34} \mathrm{~S}$ enrichments $(\approx 3-5 \%)$ in some hydrothermally altered and/or mineralized zones in dikes and gabbros within the crust, but this effect is mostly balanced by ${ }^{34} \mathrm{~S}$ depletions in the volcanic section, which is altered at low temperatures [28,42]. Consequently, the average $\delta^{34} \mathrm{~S}$ of altered oceanic crust is little changed from unaltered MORB, to a maximum of about $1 \%$ [28,42]. Unless sulfur is selectively mobilized from ${ }^{34} \mathrm{~S}$-enriched sulfide deposits ( $\delta^{34} S \approx 1.5-5 \%$ [43]) and mineralized zones in subducted ocean crust, it does not appear likely that altered ocean crust can account for the ${ }^{34} \mathrm{~S}$ enrichment of arc volcanics relative to MORB.

Sparse data exist for the distribution and isotopic composition of sulfur in deep-sea sedimentary sections, but recent results for western $\mathrm{Pa}$ cific sediments provide some important constraints. The $200-500$ m sediment sections overlying Jurassic and Cretaceous crust in the Marina and Pigafetta basins, east of the Mariana Arc, consist of pelagic clay, chalk, chert, radiolarite and volcaniclastic sandstones to claystones, all of which have low organic carbon contents, and are typical of other sections on old Pacific crust [44]. The mean bulk sediment, weighted according to sediment types drilled, contains $700 \mathrm{ppm} S$ having $\delta^{34} \mathrm{~S}=14 \%$, with most of the sulfur present as sulfate [45]. Thus, western Pacific sediment is enriched in ${ }^{34} \mathrm{~S}$ compared to altered ocean crust. If these sediments are representative of material subducted beneath the Marianas, subduction of sediments is a more likely mechanism for transporting a ${ }^{34} \mathrm{~S}$-enriched seawater sulfur component into the sub-arc mantle source than is subduction of altered crust.

In contrast to the high $\delta^{34} \mathrm{~S}$ values for western Pacific sediment, deep-sea sediment from other environments can have low $\delta^{34} \mathrm{~S}$ values. Deep-sea sediments from some restricted basins and from high-productivity equatorial zones and upwelling areas along western continental margins contain more organic carbon and greater amounts of low$\delta^{34} S$ sedimentary pyrite than western Pacific sediment, leading to lower, even negative, bulk sediment $\delta^{34} S$ values [46-48]. Subduction of such low- $\delta^{34} \mathrm{~S}$ sediments could conceivably impart low $\delta^{34} S$ values to arc volcanics from other subduction environments. This potential variation in sulfur isotopic compositions of subducted sediment could contribute to heterogeneities in sulfur isotopic compositions of sulfide in mantle material [49].

Chemical and isotopic evidence indicates that direct incorporation of sediment into the mantle source for Mariana Arc volcanics is very minor, and that the subduction component is mainly introduced by a metasomatic fluid derived from subducted sediment $[12,23,24]$. The sulfur data do not further constrain bulk mixing of sediment or fluid metasomatism, but are compatible with the metasomatic fluid interpretation.

Some constraints on subducted sediment-derived fluids come from serpentinite seamounts in the Mariana forearc [50]. Conical Seamount is an active serpentine 'mud volcano' about $120 \mathrm{~km}$ east of the island of Asuncion (slightly more than halfway from the arc volcanoes to the trench axis, Fig. 1). Fluids upwelling through serpentine on the seamount summit are characterized by low chlorinity (less than half that of seawater), and elevated $\mathrm{pH}, \mathrm{K}, \mathrm{Rb}, \mathrm{B}, \mathrm{Na} / \mathrm{Cl}, \mathrm{SO}_{4}$ and $\mathrm{H}_{2} \mathrm{~S}$ relative to seawater [51]. The fluids differ from 
those resulting from serpentinization of harzburgite, and are interpreted to be mixtures of seawater and water derived from dehydration reactions in the subducting slab, $30 \mathrm{~km}$ below [51]. Fluids driven off from the slab serpentinize the overlying mantle, and serpentine diapirs move upward and eventually protrude onto the seafloor, forming serpentinite seamounts that act as conduits through which subduction-derived fluids pass into the ocean [50,51]. Much of the dehydration of the subducting slab may occur beneath the fore-arc, with hydrated, metasomatized fore-arc mantle material being dragged downward by the subducting slab to higher pressures and temperatures, where partial melting of hydrated peridotite occurs [52]. Sulfide comprises less than $0.5 \%$ of the total sulfur in the fluids on Conical Seamount, so the measured $\delta^{34} \mathrm{~S}$ value of sulfate $(13.5 \%)$ is representative of total sulfur in the fluid [53]. If it is assumed that the end-member slab-derived fluid is fresh water (from mineral dehydration reactions), extrapolation to zero chlorinity gives a fluid $\delta^{34} \mathrm{~S}$ of about $8 \%$. Any exchange of slabderived and mantle sulfur $\left(\delta^{34} S \sim 0 \%\right.$ ) during metasomatism and serpentinization reactions in the mantle would only serve to lower the $\delta^{34} S$ of the fluids exiting from Conical Seamount and imply that the slab-derived fluid had even higher $\delta^{34} \mathrm{~S}$ than estimated. These values $(8-13.5 \% 0)$ are roughly consistent with that for western Pacific sediment given above, and with a high- $\delta^{34}$ S sediment-derived metasomatic fluid penetrating the sub-arc mantle wedge. If a metasomatic fluid having $\delta^{34} \mathrm{~S}=14 \%$ reacts with a mantle containing MORB-like sulfur $\left(\delta^{34} \mathrm{~S}=0.1 \%\right.$, values of 4-5\% in the arc volcanics indicate that approximately $30-35 \%$ of the sulfur in the source is metasomatic.

\subsection{Sulfur in the Mariana back-arc trough}

Basalts from the Mariana Trough exhibit a range of major and trace element and isotopic compositions, from similar to MORB to those that are transitional to arc basalts $[14,15,54]$. Such variations are interpreted as resulting from metasomatism of a depleted sub-arc mantle by fluids derived from the subducting slab $[14,15,54]$. This metasomatic component is present at least locally at $18^{\circ} \mathrm{N}$ but imparts a strong arc signature to the rocks from $22^{\circ} \mathrm{N}$ in the trough [14,15,54]. The more 'arc-like' trough rocks (from $22^{\circ} \mathrm{N}$ and 18469 from $18^{\circ} \mathrm{N}$ ) are not enriched in ${ }^{34} \mathrm{~S}$ relative to the other trough samples, however, as might be expected. Although the mantle source of Mariana Trough lavas has been affected by fluids derived from the subducting slab, not all of the trough lavas exhibit trace element or radiogenic isotope enrichment compared to MORB. Stolper and Newman [55] attribute this to a 'chromatographic' effect of changing fluid composition as the metasomatic fluid passes through and reacts with the sub-arc mantle. According to this interpretation, by the time the subduction-derived fluid reaches the source region of the back-arc trough volcanics it has reacted with enough mantle that it is essentially in equilibrium with the mantle and the slab signature is lost. In contrast, the fluid added to the source region of Mariana Arc volcanics interacts with less mantle and generally retains the slab signature. The data presented here for sulfur in the Mariana Arc and Trough volcanics are consistent with this 'chromatographic' effect and absence of the ${ }^{34} \mathrm{~S}$-enriched slab signature in the back-arc trough lavas (Fig. 7).

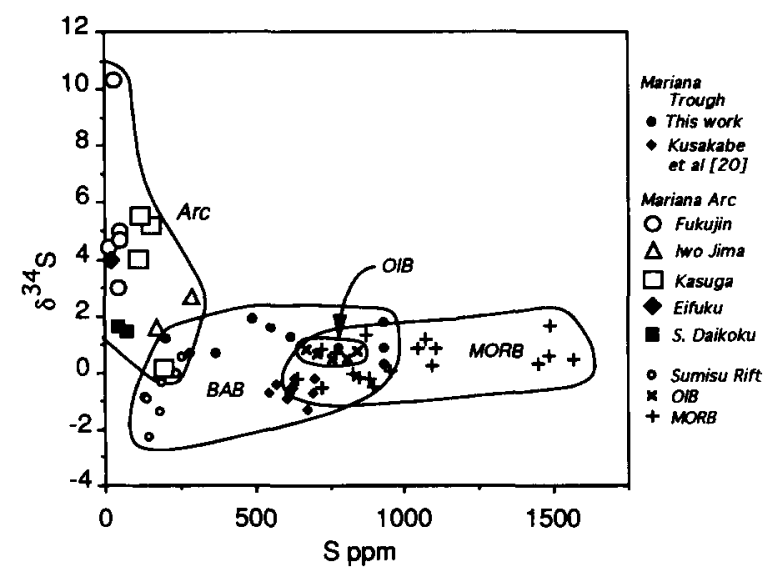

Fig. 7. $\delta^{34} \mathrm{~S}$ vs. $\mathrm{S}$ content for Mariana Arc and back-arc trough submarine glass samples, together with data for submarine glasses from the Sumisu back-arc rift, MORB and OIB (as represented by Kilauea) for comparison. The arc rocks have lower $S$ contents and higher $\delta^{34} S$ values than back-arc basin, MORB and OIB glasses (data from Table 1 $[16,17,19-21,56])$. 


\section{Summary and conclusions}

Analyses of submarine volcanic glasses provide important new constraints on sulfur systematics in island-arc and back-arc environments. Volcanic glasses from the Mariana Island Arc are enriched in ${ }^{34} \mathrm{~S}\left(\delta^{34} \mathrm{~S}=\right.$ up to $10.3 \%$, mean $=$ $3.8 \%$ ) and depleted in $\mathrm{S}(20-290 \mathrm{ppm}$, mean $=$ $100 \mathrm{ppm}$ ) relative to MORB. The ${ }^{34} \mathrm{~S}$ enrichment of the arc rocks is attributed to the presence of a subduction-related seawater sulfur component in the sub-arc mantle source. The seawater component is most likely derived from subducted sediments rather than altered ocean crust. Although not constrained by the sulfur data, other trace element and isotopic data suggest metasomatism of depleted sub-arc mantle by fluids derived from subducted sediment, rather than by direct incorporation of sediment.

Sulfide minerals formed in trace amounts lining vesicles in the arc rocks by reaction of sulfur in the vapor with iron in the vesicle walls. Sulfide inclusions in olivine, plagioclase and magnetite phenocrysts indicate saturation of melts with sulfide throughout much of their pre-eruptive crystallization history and loss of some sulfur through separation of immiscible sulfide during fractional crystallization. In contrast, the lack of sulfides in glass and the absence of a correlation between $\mathrm{S}$ contents and $\mathrm{FeO}^{\mathrm{T}}$ suggest other controls on sulfur contents during eruption. The generally low $\mathrm{S}$ contents of the arc rocks are attributed to vapor-melt equilibria control of sulfur contents and loss of $S$ in a vapor phase near the minimum in solubility of $\mathrm{S}$ in silicate melts at $f \mathrm{O}_{2} \approx \mathrm{NNO}$ (nickel-nickel-oxide). Whereas loss of $\mathrm{S}$ in the vapor phase contributed to the low $\mathrm{S}$ contents, this process did not significantly affect the $S$ isotopic compositions of the melts.

The back-arc Mariana Trough basalts contain 200-930 ppm S and have $\delta^{34} \mathrm{~S}$ values of $+1.1 \pm$ $0.5 \%$. These $S$ contents and $\delta^{34} S$ values overlap those for the arc and MORB. Back-arc trough basalts that are 'arc-like' based on trace element and $\mathrm{Sr}$ isotopic compositions do not exhibit the ${ }^{34} \mathrm{~S}$ enrichment of the arc rocks, however. The lack of a ${ }^{34} \mathrm{~S}$-rich subduction signature in the trough lavas may be due to a chromatographic effect, whereby slab-derived metasomatic fluid reacts with greater amounts of mantle along the longer pathway to the source area for the trough volcanics and loses its slab sulfur signature, whereas the ${ }^{34} \mathrm{~S}$-enriched fluid retains its slab signature throughout most of the arc mantle source area.

Gases extracted from vesicles in both arc and back-arc volcanics are predominantly $\mathrm{H}_{2} \mathrm{O}$, with minor $\mathrm{CO}_{2}$ and traces of $\mathrm{H}_{2} \mathrm{~S}$ and $\mathrm{SO}_{2} . \mathrm{CO}_{2}$ has $\delta^{13} \mathrm{C}$ values of -2.1 to $-13.1 \%$, which are similar to those for $\mathrm{CO}_{2}$ in MORB. These MORB-like values suggest that subduction of organic carbon may not be necessary to produce low $\delta^{13} \mathrm{C}$ values of carbon in Mariana Arc and back-arc trough volcanics. More analyses are required to resolve this question, however.

\section{Acknowledgements}

This work was supported by NSF OCE8816878, OCE-9096115 and OCE-9018136. We thank P. Fryer, J. Hawkins and R. Stern for providing samples and J. Burdett for assistance in the laboratory. Discussions with S. Bloomer, P. Fryer, A. Hochstaeder, R. Lange, J. Luhr and E. Stolper helped develop the ideas presented here. Comments on an early version by $\mathrm{R}$. Carmody and L. Woodruff led to significant improvements in the manuscript. M. Chaussidon and K. Nilsson provided particularly thorough and constructive reviews.

\section{References}

1 A. Sasaki and S. Ishihara, Sulfur isotopic composition of the magnetite series and ilmenite series granitoids in Japan, Contrib. Mineral. Petrol. 68, 107-115, 1979.

2 R.O. Rye, J.F. Luhr and M.D. Wasserman, Sulfur and oxygen isotopic systematics of the 1982 eruptions of El Chichon volcano, Chiapas, Mexico, J. Vulcanol. Geotherm. Res. 23, 109-123, 1984.

3 A. Ueda and H. Sakai, Sulfur isotope study of Quaternary volcanic rocks from the Japanese Island Arc, Geochim. Cosmochim. Acta 48, 1837-1848, 1984.

4 J.D. Woodhead, R.S. Harmon and D.G. Fraser, O, S, Sr, and $\mathrm{Pb}$ isotope variations in volcanic rocks from the Northern Mariana Islands: Implications for crustal recycling in intraoceanic arcs, Earth Planet. Sci. Lett. 83, 39-52, 1987.

$5 \mathrm{~S}$. Ishihara and A. Sasaki, Sulfur isotopic ratios of the magnetite-series and ilmenite-series granitoids of the Sierra Nevada batholith - a reconnaissance study, Geology 17, 788-791, 1989. 
6 M.O. Garcia, N.W.K. Liu and D.W. Muenow, Volatiles in submarine volcanic rocks from the Mariana Island Arc and trough, Geochim. Cosmochim. Acta 43, 305-312, 1979.

7 J.G. Moore and J.G. Schilling, Vesicles, water, and sulfur in Reykjanes Ridge basalts, Contrib. Mineral. Petrol. 41, 105-118, 1973.

8 D.M. Hussong, S. Uyeda et al., Init. Rep. DSDP 60, 1981.

9 D.A. Wood, N.G. Marsh, J. Tarney, J.L. Joron, P. Fryer and $\mathrm{M}$. Treuil, Geochemistry of igneous rocks recovered from a transect across the Mariana Trough, Arc, Fore-arc and Trench, sites 453 through 461, DSDP Leg 60, Init. Rep. DSDP 60, 611-645, 1981.

10 S.H. Bloomer, R.J. Stern, E. Fisk and C.H. Geschwind, Shoshonitic volcanism in the Northern Mariana Arc 1. Mineralogic and major and trace element characteristics, J. Geophys. Res. 94, 4469-4496, 1989.

11 P.N. Lin, R.J. Stern and S.H. Bloomer, Shoshonitic volcanism in the northern Mariana Arc 2. Large-ion lithophile and rare earth element abundances: Evidence for the source of incompatible element enrichments in intra-oceanic arcs, J. Geophys. Res. 94, 4497-4514, 1989.

12 P.N. Lin, R.J. Stern, J. Morris and S.H. Bloomer, Nd- and Sr-isotopic compositions of lavas from the northern Mariana and southern volcano arcs: implications for the origin of island arc melts, Contrib. Mineral. Petrol. 105, 381-392, 1990.

13 M.C. Jackson, Petrology and petrogenesis of recent submarine volcanoes from the northern Mariana arc and back-arc basin, Ph.D. Dissert., Univ. Hawaii, 1989.

14 J.W. Hawkins, P.F. Lonsdale, J.D. Macdougall and A.M. Volpe, Petrology of the axial ridge of the Mariana Trough backarc spreading center, Earth Planet. Sci. Lett. 100, 226-250, 1990.

15 R.J. Stern, P.N. Lin, J.D. Morris, M.C. Jackson, P. Fryer, S.H. Bloomer and E. Ito, Enriched back-arc basin basalts from the northern Mariana Trough: implications for the magmatic evolution of back-arc basins, Earth Planet. Sci. Lett. 100, 210-225, 1990.

16 H. Sakai, T.H. Casadevall and J.G. Moore, Chemistry and isotope ratios in basalts and volcanic gases at Kilauea Volcano, Hawaii, Geochim. Cosmochim. Acta 46, 229-738, 1982.

17 H. Sakai, D.J. Des Marais, A. Ueda and J.G. Moore, Concentrations and isotope ratios of carbon, nitrogen, and sulfur in ocean-floor basalts, Geochim. Cosmochim. Acta 48, 2433-2441, 1984.

18 A. Sasaki, Y. Arikawa and R.E. Folinsbee, Kiba reagent method of sulfur extraction applied to isotopic work, Geol. Surv. Jpn. Bull. 30, 241-245, 1979.

19 M. Chaussidon, S.M.F. Sheppard and A. Michard, Hydrogen, sulphur and neodymium isotope variations in the mantle beneath the EPR at $12^{\circ} 50^{\prime} \mathrm{N}$, Geochem. Soc. Spec. Publ. 3, 325-337, 1991.

20 M. Kusakabe, S. Mayeda and E. Nakamura, S, O, and Sr isotope systematics of active vent materials from the Mariana backarc basin spreading axis at $18^{\circ} \mathrm{N}$, Earth Planet. Sci. Lett. 100, 275-282, 1990.

21 A.G. Hochstaedter, J.B. Gill, M. Kusakabe, S. Newman, M. Pringle, B. Taylor and P. Fryer, Volcanism in the
Sumisu Rift, I. Major element, volatile, and stable isotope geochemistry, Earth Planet. Sci. Lett. 100, 179-194, 1990.

22 J.G. Moore, J.N. Batchelder and C.G. Cunningham, $\mathrm{CO}_{2}$ filled vesicles in mid-ocean basalt, J. Volcanol. Geotherm. Res. 2, 309-327, 1977.

23 P.N. Lin, Trace element and isotopic characteristics of western Pacific pelagic sediments: Implications for the petrogenesis of Mariana Arc magmas, Geochim. Cosmochim. Acta 56, 1641-1654, 1992.

24 J.D. Woodhead, Geochemistry of the Mariana arc (western Pacific): Source composition and processes, Chem. Geol. 76, 1-24, 1989.

25 P.R. Hamlyn, R.R. Keays, W.E. Cameron, A.J. Crawford and H.M. Waldron, Precious metals in magnesian low-Ti lavas: Implications for metallogenesis and sulfur saturation in primary magmas, Geochim. Cosmochim. Acta 49, 1797 $1811,1985$.

26 C.L. Peach, E.A. Mathez and R.R. Keays, Sulfide meltsilicate melt distribution coefficients for noble metals and other chalcophile elements as deduced from MORB: Implications for partial melting, Geochim. Cosmochim. Acta 54, 3379-3390, 1990.

27 P. Wallace and I.S.E. Carmichael, Sulfur in basaltic magmas, Geochim. Cosmochim. Acta 56, 1863-1874, 1992.

28 J.C. Alt and T.F. Anderson, Mineralogy and isotopic composition of sulfur in layer 3 gabbros from the Indian Ocean, Hole 735B, Proc. ODP, Sci. Results 118, 113-125, 1991.

29 G. Hartmann and K.H. Wedepohl, The composition of peridotite tectonites from the Ivrea complex, northern Italy: Residues from melt extraction, Geochim. Cosmochim. Acta 57, 1761-1782, 1993.

30 T. Katsura and S. Nagashima, Solubility of sulfur in some magmas at 1 atmosphere, Geochim. Cosmochim. Acta 38, 517-531, 1974.

31 M.R. Carroll and M.J. Rutherford, Sulfide and sulfate saturation in hydrous silicate melts, J. Geophys. Res. 90C, 601-612, 1985.

32 J.F. Luhr, Experimental phase relations of water- and sulfur-saturated arc magmas and the 1982 eruptions of El Chichon Volcano, J. Petrol. 31, 1071-1114, 1990.

$33 \mathrm{~K}$. Nilsson, Oxidation state and sulfur concentration in Lau Basin basalts, Proc. ODP, Sci. Results 135, submitted, 1993.

34 K. Nilsson and C. Peach, Sulfur speciation, oxidation state, and sulfur concentrations in backarc and island arc magmas, Geochim. Cosmochim. Acta, in press, 1993.

35 D.R. Haughton, P. Roeder and B.J. Skinner, Solubility of sulfur in mafic magmas, Econ. Geol. 69, 451-467, 1974.

36 I.O. Oshin and J.H. Crockett, Noble metals in the Thetford Mines ophiolites, Quebec, Canada. Part II: Distribution of gold, silver, iridium, platinum and palladium in the Lac de l'Est volcano-sedimentary section, Econ. Geol. 81, 931-945, 1986.

37 I.S.E. Carmichael and M.S. Ghiorso, The effect of oxygen fugacity on the redox state of natural liquids and their crystallizing phases, in: Modern Methods of Igneous Petrology: Understanding Magmatic Processes, J. Nicholls and K. Russell, eds., Min. Soc. Am., Chelsea, 1990. 
38 P. Allard, The origin of hydrogen, carbon, sulfur, nitrogen and rare gases in volcanic exhalations: Evidence from isotope geochemistry, in: Forecasting Volcanic Events, $\mathbf{H}$. Tazieff and J.C. Sabrous, eds., pp. 337-397, Elsevier, 1983.

39 R.P.E. Poorter, J.C. Varekamp, R.J. Poreda, M.J. van Bergen and R. Kruelen, Chemical and isotopic compositions of volcanic gases from the east Sunda and Banda arcs, Indonesia, Geochim. Cosmochim. Acta 55, 37953807, 1991.

$40 \mathrm{~F}$. Pineau, M. Javoy and $\mathrm{Y}$. Bottinga, ${ }^{13} \mathrm{C} /{ }^{12} \mathrm{C}$ ratios of rocks and inclusions in popping rocks of the Mid-Atlantic Ridge and their bearing on the problem of isotopic composition of deep-seated carbon, Earth Planet. Sci. Lett. 29, 413-421, 1976.

41 D.P. Mattey, R.H. Carr, I.P. Wright and C.T. Pilinger, Carbon isotopes in submarine basalts, Earth Planet. Sci. Lett. 70, 196-206, 1984.

42 J.C. Alt, T.F. Anderson and L. Bonnell, The geochemistry of sulfur in a $1.3 \mathrm{~km}$ section of hydrothermally altered oceanic crust, DSDP Hole 504B, Geochim. Cosmochim. Acta 53, 1011-1023, 1989.

43 L.G. Woodruff and W.C. Shanks III, Sulfur isotope study of chimney minerals and vent fluids from $21^{\circ} \mathrm{N}$, East Pacific Rise: Hydrothermal sulfur sources and disequilibrium sulfate reduction, J. Geophyus. Res. 93, 4562-4572, 1988.

44 Y. Lancelot, R. Larson et al., Proc. ODP, Init. Rep. 129, 488 pp., 1992.

45 J.C. Alt and J. Burdett, Sulfur in Pacific deep-sea sediments, ODP Leg 129, and implications for cycling of sediment in subduction zones, Proc. ODP, Sci. Results 129, 283-294, 1992.

$46 \mathrm{M}$. Lew, The distribution of some major and trace elements in sediments of the Atlantic Ocean (DSDP samples). 1. The distribution of sulfphur, sulphur isotopes, and $\mathrm{Mn}$, $\mathrm{Fe}, \mathrm{Zn}$, and $\mathrm{Cu}$, Chem. Geol. 33, 205-224, 1981.

47 D.R. Canfield, Sulfate reduction in deep sea sediments, Am. J. Sci. 291, 177-188, 1991.
48 J.R. Mossmann, A.C. Aplin, C.D. Curtis and M.L. Coleman, Geochemistry of inorganic and organic sulfphur in organic-rich sediments from the Peru Margin, Geochim. Cosmochim. Acta 55, 3581-3596, 1991.

49 M. Chaussidon and J.P. Lorand, Sulphur isotope composition of orogenic spinel lherzolite massifs from Ariege (North-eastern Pyrenees, France): an ion microprobe study, Geochim. Cosmochim. Acta 54, 2835-2846, 1990.

50 P. Fryer, K.L. Saboda, L.E. Johnson, M.E. Mackay, G.F. Moore, and P. Stoffers, Conical seamount: SeaMARC II, ALVIN submersible, and seismic reflection studies, Proc. ODP, Init. Rep. 125, 69-80, 1990.

51 M.J. Mottl, Pore waters from serpentinite seamounts in the Mariana and Izu-Bonin forearcs, Leg 125: evidence for volatiles from the subducting slab, Proc. ODP, Sci. Results 125, 373-386, 1993.

$52 \mathrm{Y}$. Tatsumi, Migration of fluid phases and genesis of basalt magmas in subduction zones, J. Geophys. Res. 94, 46974707, 1989.

53 M.J. Mottl and J.C. Alt, Minor and trace element and sulfur isotopic compositon of pore waters from sites 778 through 786, Proc. ODP, Sci. Results 125, 683-688, 1993.

54 A.M. Volpe, J.D. Macdougall, G.W. Lugmair, J.W. Hawkins and $P$. Lonsdale, Fine scale isotopic variationin Mariana Trough basalts: evidence for heterogeneity and a recycled component in backarc basin mantle, Earth Planet. Sci. Lett. 100, 251-264, 1990.

55 E. Stolper and S. Newman, The role of water in the petrogenesis of Mariana trough magmas, Earth. Planet. Sci. Lett., submitted, 1992.

56 K. Kanehira, S. Yui, H. Sakai and A. Sasaki, Sulphide globules and sulphur isotope ratios in the abyssal tholeiite from the Mid-Atlantic Ridge near $30^{\circ} \mathrm{N}$ latitude, Geochem. J. 7, 89-96, 1973.

57 A.W. Hofmann, Chemical differentiation of the Earth: the relationship between mantle, continental crust, and oceanic crust, Earth Planet. Sci. Lett. 90, 297-314, 1988. 